Portland State University

PDXScholar

8-1-2016

\title{
Tools for Assisting Low-Income Households with Finding Location-Efficient Housing
}

Andrée Tremoulet

Portland State University, andree@commonworksconsulting.com

Follow this and additional works at: https://pdxscholar.library.pdx.edu/trec_reports

Part of the Transportation Commons

Let us know how access to this document benefits you.

\section{Recommended Citation}

Tremoulet, A., Tools for Assisting Low-Income Households with Finding Location-Efficient Housing. NITCTT-983. Portland, OR: Transportation Research and Education Center (TREC) 2016. https://doi.org/ 10.15760/trec.153

This Report is brought to you for free and open access. It has been accepted for inclusion in TREC Final Reports by an authorized administrator of PDXScholar. Please contact us if we can make this document more accessible: pdxscholar@pdx.edu. 


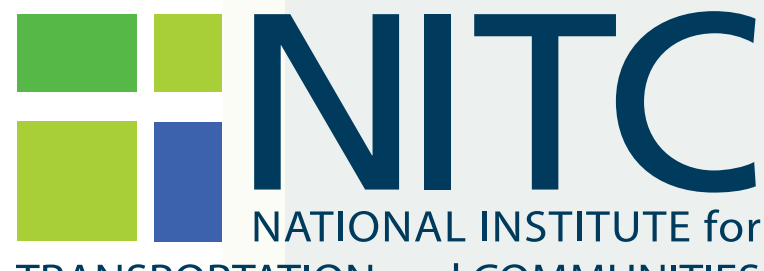

TRANSPORTATION and COMMUNITIES

FINAL REPORT

Tools for Assisting Low-Income Households with Finding Location-Efficient Housing

NITC-TT-983 August 2016

NITC is the U.S. Department of Transportation's national university transportation center for livable communities.

HITEC 


\section{TOOLS FOR ASSISTING LOW-INCOME HOUSEHOLDS WITH FINDING LOCATION-EFFICIENT HOUSING A TECH TRANSFER PROJECT}

Final Report

NITC-TT-983

by

Andrée Tremoulet

Portland State University

for

National Institute for Transportation and Communities (NITC)

P.O. Box 751

Portland, OR 97207

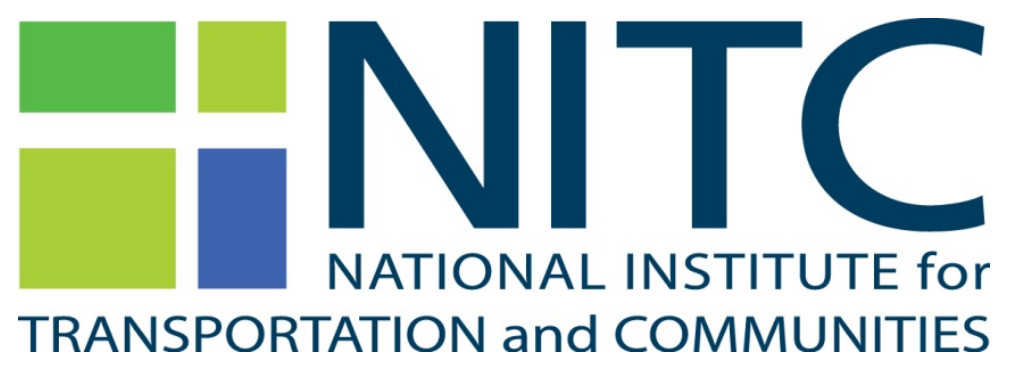

August 2016 



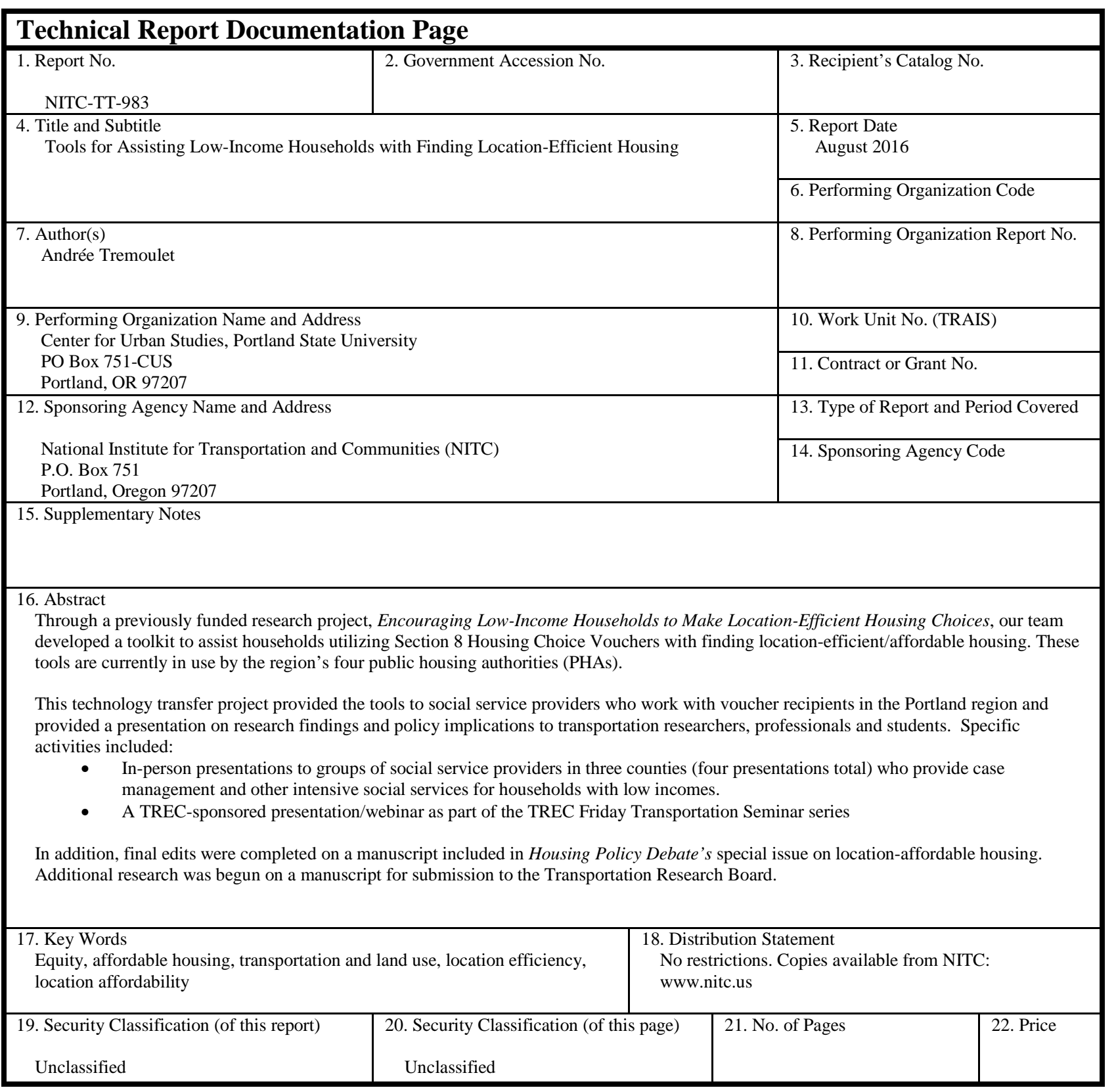





\section{ACKNOWLEDGEMENTS}

This project was funded by the National Institute for Transportation and Communities (NITC).

\section{DISCLAIMER}

The contents of this report reflect the views of the authors, who are solely responsible for the facts and the accuracy of the material and information presented herein. This document is disseminated under the sponsorship of the U.S. Department of Transportation University Transportation Centers Program in the interest of information exchange. The U.S. Government [assumes no liability for the contents or use thereof. The contents do not necessarily reflect the official views of the U.S. Government. This report does not constitute a standard, specification, or regulation. 



\section{TABLE OF CONTENTS}

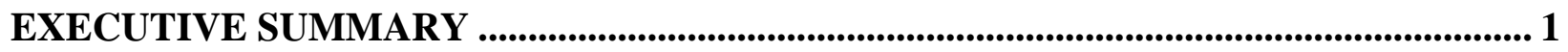

1.0 PRESENTATIONS TO SOCIAL SERVICE PROVIDERS ........................................ 3

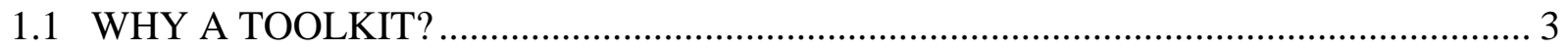

1.2 WHAT IS IN THE TOOLKIT? .............................................................................. 3

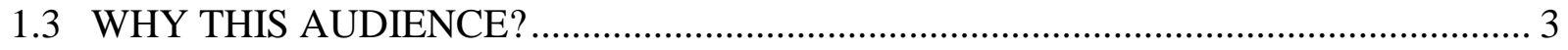

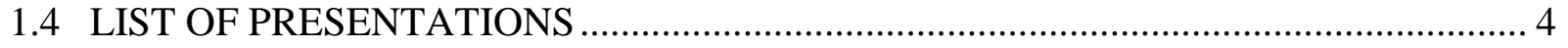

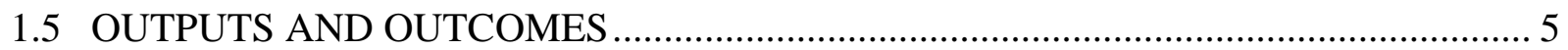

1.6 PRESENTATION TO TRANSPORTATION PROFESSIONALS AND RESEARCHERS

2.0 ADDITIONAL TECH TRANSFER ACTIVITIES ...................................................... 7

2.1 HOUSING POLICY DEBATE JOURNAL ARTICLE ............................................. 7

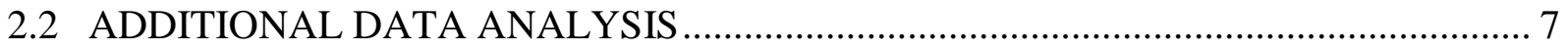

\section{APPENDICES}

APPENDIX A: PRESENTATION FOR SOCIAL SERVICE AGENCIES 



\section{EXECUTIVE SUMMARY}

Through a previously funded research project, Encouraging Low-Income Households to Make Location-Efficient Housing Choices, our team developed a toolkit to assist households utilizing Section 8 Housing Choice Vouchers with finding location-efficient/affordable housing. These tools are currently in use by the region's four public housing authorities (PHAs).

This technology transfer project provided the tools to social service providers in the Portland region and a presentation on research findings and policy implications to transportation researchers, professionals and students. Specific activities included:

- In-person presentations to groups of social service providers in three counties (four presentations total) who provide case management and other intensive social services for households with low incomes.

- A TREC-sponsored presentation/webinar as part of the TREC Friday Transportation Seminar series

In addition, final edits were completed on a manuscript included in Housing Policy Debate's special issue on location-affordable housing. Additional research was begun on a manuscript to be submitted to the Transportation Research Board, with submission anticipated to occur in summer 2016. 



\subsection{PRESENTATIONS TO SOCIAL SERVICE PROVIDERS}

\subsection{WHY A TOOLKIT?}

When people choose a place to live, they are not only choosing a home; they are also choosing how they are going to get around and how long it will take them to get around. Transportation choices (e.g., mode, routes and distances) are implicit in the choice of a place to live. This dual nature of housing choice is sometimes called "the combined cost of place."

The people who can afford to spend the least on the combined cost of place are low-income households. But these are the very people who may have limited information about housing costs associated with various housing options. The Portland region's four public housing authorities (PHAs) solicited our help with developing a toolkit that could be used by clients with housing vouchers when they are looking for a place to live.

The process of developing the toolkit is fully described in our research report, Encouraging LowIncome Households to Make Location-Efficient Housing Choices

(http://trec.pdx.edu/research/project/751/Encouraging_LowIncome_Households_to_Make_Location-Efficient_Housing_Choices).

\subsection{WHAT IS IN THE TOOLKIT?}

The toolkit contains the following elements:

- An introductory video

- An introductory brochure

- Information about how to use Apartment Finder by Walk Score as a way to find potential location-affordable housing options.

- A housing search checklist that integrates transportation considerations into the list of things that one should consider when evaluating a place as a potential place to live

- A transportation cost estimator worksheet

The introductory brochure was customized for each PHA, and the rest of the tools are the same for all PHAs. The PHAs have made the toolkits available on their websites; links are provided in the section below.

\subsection{WHY THIS AUDIENCE?}

One of the discoveries that we made as part of our primary research project is that PHA staff, due to the large quantity of people they serve, are limited in the amount of individualized attention that they are able to provide to clients. As a result, housing services-such as 
orientations for people first receiving a housing voucher-may be provided in a group or class setting. While staff typically do schedule an individual meeting to review the amount of subsidy (voucher amount) that a client will receive, the information about how to find housing is typically offered as a class. There's no time for individualized problem solving around specific challenges with finding housing, like a lack of transportation or language/literacy barriers.

Sometimes households that receive housing vouchers also receive individualized "case management” services from another agency. Staff at these agencies may have caseloads that allow them to be in contact with their clients on a periodic basis and provide more intensive social services. Because some households may not have the ability to use some of the elements of the toolkit unaided, our goal in this project was to put the toolkit in the hands of human service agency staff who work with low-income clients looking for housing.

In Washington and Clackamas counties, lead staff from social service agencies meet monthly for informational meetings and networking. These meetings occur as part of the "Continuum of Care” network established to coordinate services for people without a permanent home. However, many of these agencies also provide services to households with low incomes who do have housing. Our presentation occurred as part of these meetings and thus reached the agencies most likely to use the information provided. In Washington County, we also presented to a group of county staff from multiple areas (including land use, public health, housing and social services) who collaborate to reduce chronic health conditions.

Portland has a different approach to coordinating services for homeless individuals and, given the high number of agencies that could be involved, there is no one common meeting space. Thus, instead of meeting with a Continuum of Care network, we presented the toolkit to a group of homeless prevention service providers convened by Home Forward (the PHA for Portland/Multnomah County) for that purpose.

\subsection{LIST OF PRESENTATIONS}

Smart Moves: New Tools for Finding Location-Efficient Housing. Presentation consisted of a PowerPoint presentation, the introductory video, distribution of printed tools, and discussion.

Presentation 1: 1/26/16 (Tuesday) 9 a.m. Washington County Chronic Disease Prevention group of Community Health Improvement Plan

- 18 attendees, representing county staff in public health (most attendees), planning, housing

- Contact: Rose Sherwood Rose_Sherwood@co.washington.or.us

- Washington County Conference Center-Hillsboro, Room 103

- County website: http://www.co.washington.or.us/movetools

Presentation 2: 1/27/16 (Wednesday) 9 a.m. Clackamas County Continuum of Care Network

- 32 attendees, primarily social service agency/nonprofit staff involved with homelessness prevention and services 
- Contact: Mark Sirois MarkSir@co.clackamas.or.us Abby Ahern AbbyAhe@co.clackamas.or.us

- Address: 2051 Kaen Road, Oregon City Room 255

- Website: http://www.clackamas.us/housingauthority/otherresources.html

Presentation 3: 2/3/16 (Wednesday) 8:35 a.m. Washington County Continuum of Care Network (HSSN)

- 43 attendees, primarily social service agency/nonprofit staff involved with homelessness prevention and services

- Contact: Annette Evans Annette_Evans@co.washington.or.us ; Veronica Clevidence Veronica_Clevidence@co.washington.or.us

- Address: Beaverton City Hall, 12725 SW Millikan Way, Room 390 (third-floor training room)

- County website: http://www.co.washington.or.us/movetools

Presentation 4: 3/3/16 (Thursday) 1:30 p.m. Housing Service Providers in Portland

- 8 attendees, primarily front-line staff working to find housing for low-income individuals and households

- Contact: Rebecca Nesbit

- Address: 135 SW Ash St, Portland, OR $972045^{\text {th }}$ floor Metolius Room

- Website: http://www.hapdx.org/find-a-home/learn-about-transportation-costs

\subsection{OUTPUTS AND OUTCOMES}

Slightly more than 100 agency staff in the Portland metro region attended these presentations and had the opportunity to take printed copies of the toolkit with them. Additional staff who did not attend the meeting but received e-mail invitations were able to access electronic versions. In addition, the staff who attended may have shared the information with others in their agencies. As indicated above, staff can access electronic copies and links through PHA websites.

This project did not include a follow-up survey to find out if and how staff used the tools. However, given the Portland region's extremely tight rental housing market (rental vacancies around 3\%), it is possible that the toolkit is being used more to help households with vouchers identify any and all potential housing options rather than optimize among options.

\subsection{PRESENTATION TO TRANSPORTATION PROFESSIONALS AND RESEARCHERS}

In addition to the presentations to social service agencies, a presentation was also made to the research and professional community through the TREC Friday Seminar Series. The information about the presentation, including a link to the complete seminar, can be found below:

Edged Out: 3/4/14 (Friday) 12 p.m. TREC Friday Seminar Series 
- Edged Out http://trec.pdx.edu/events/professional-development/edged-out-locationefficient-housing-and-low-income-households

- 1 hour total, with Q \& A (35-minute presentation)

Instead of focusing on the toolkit, this presentation discussed the concepts of location-efficient and affordable housing and the combined cost of place. It introduced the challenges of finding housing with a housing voucher in a tight real estate market and discussed the search process. It also presented the research findings and discussed the implications for transportation planners. 


\subsection{ADDITIONAL TECH TRANSFER ACTIVITIES}

Although these activities were not originally scoped as part of this project, we were able to leverage the work completed as part of the original research project into two additional manuscripts. One has been accepted for publication and the other will be submitted for publication in August 2016.

\subsection{HOUSING POLICY DEBATE JOURNAL ARTICLE}

The citation for the article is as follows:

Tremoulet, Andrée, Dann, Ryan J., \& Adkins, Arlie. (2016, April 15). Moving to Location Affordability? Housing Choice Vouchers and Residential Relocation in the Portland, Oregon, Region. Housing Policy Debate.

http://doi.org/10.1080/10511482.2016.1150314.

The abstract is as follows:

Location affordability measures a household's combined cost of housing and transportation. Low-income households have the most to gain from housing with lower transportation costs. This research analyzes whether Housing Choice Voucher Program households - participants in a program designed to provide low-income households with a greater degree of housing choice-are able to choose housing that lowers their transportation costs in a metropolitan region with a compact, vital urban core. A mixedmethods approach is used to investigate the differences in location affordability and efficiency among 2,026 voucher recipients who moved within the Portland, OR, region during 2012-2013. Location mattered to movers, but in some unexpected ways. Urban movers relocated to less location-efficient areas, whereas suburban movers' location efficiency remained stable. In tight housing markets, voucher holders may be edged out of location-efficient neighborhoods and thus incur increased transportation costs.

\subsection{ADDITIONAL DATA ANALYSIS}

Additional analysis of 185 surveys of Housing Choice Voucher Program participants from the Home Forward (the PHA for Multnomah County, including the City of Portland) was completed. The analysis looked at the preferences of 185 people with very low incomes regarding transportation modes used for frequently occurring non-work trips. The perceptions, preferences, attitudes and social norms relating to transportation were compared and contrasted for three groups: those who use transit exclusively, those who use an auto exclusively, and those who use a combination of both modes.

Work on a manuscript to be submitted to the Transportation Research Board will continue beyond the completion of this grant, with an estimated submission date in summer 2016. 



\title{
APPENDIX A
}

\section{PRESENTATION FOR SOCIAL SERVICE AGENCIES}

\author{
Smart Moves: New Tools for Finding Location-Efficient Housing
}




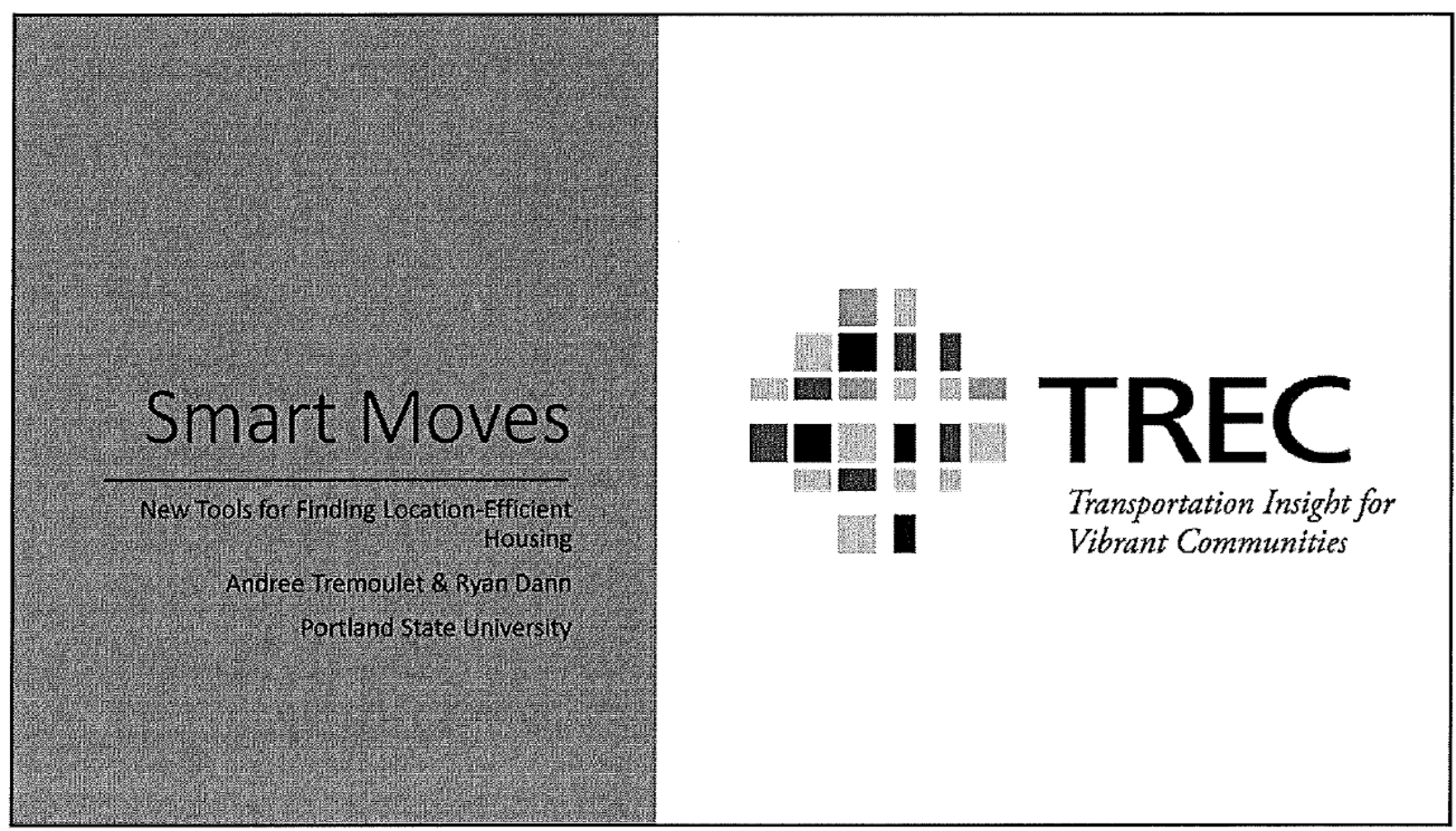

\section{Why Do Transportation Costs Matter?}

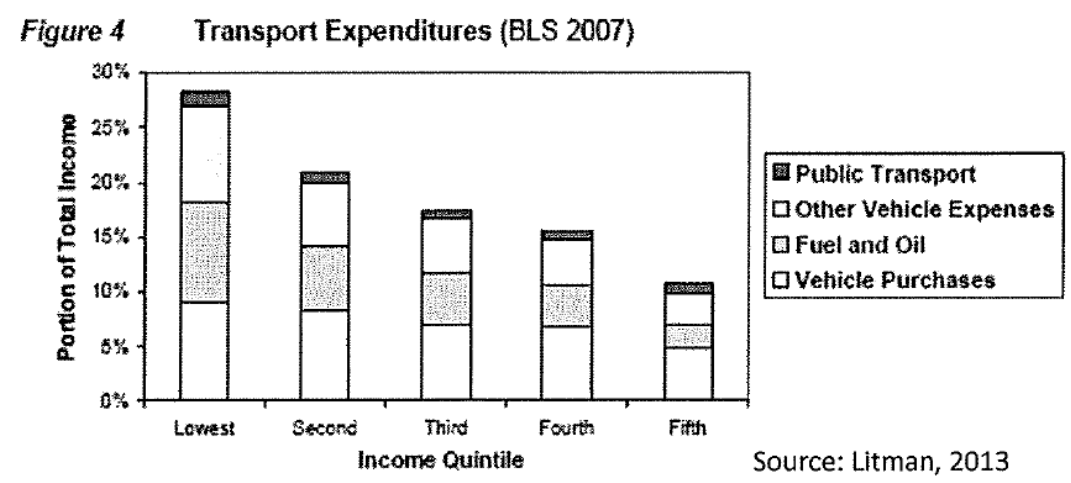

Households with low incomes have the most to gain from lowering their transportation costs. 


\section{Location-Efficient Housing}

The combined cost of place $=$ Housing + Transportation Costs
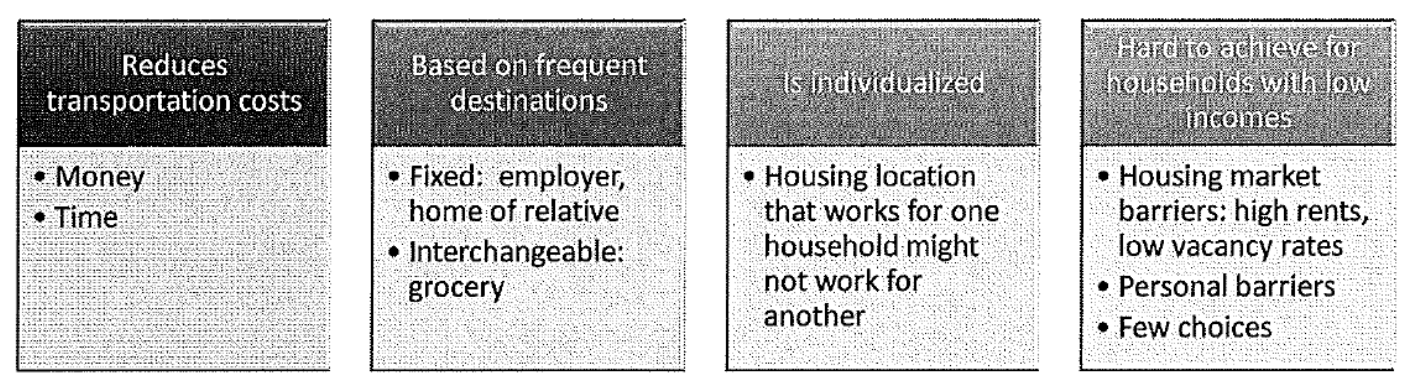

\section{Creating A Toolbox}
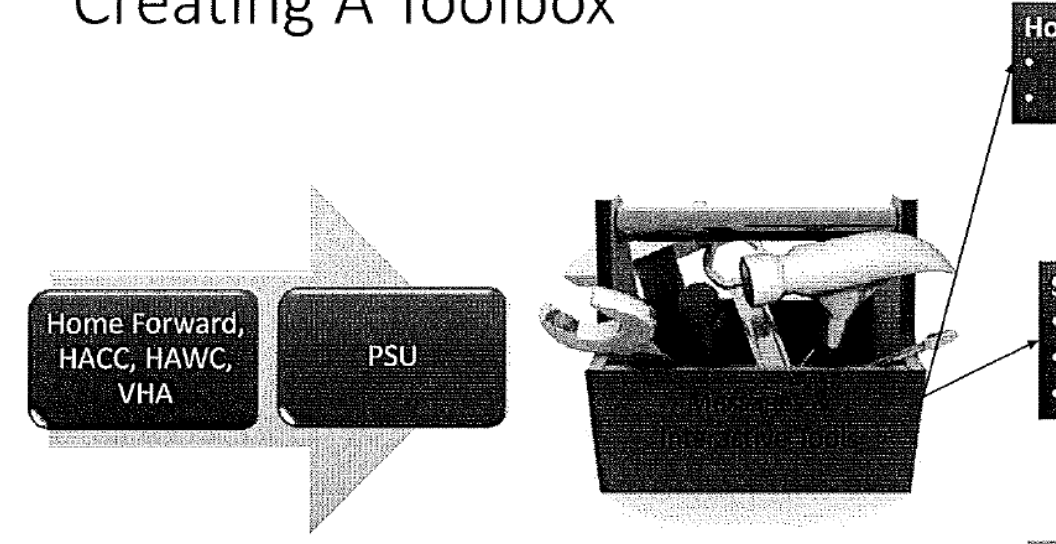

Touseholds with Housing Vouchers

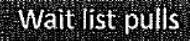

Current participants who move

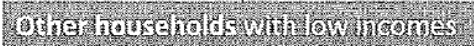
Who ar closing roc helusing 


\section{What's In the Toolbox?}

\section{Introductory Brochure}

\section{Video}

Using Walk Score Apartment Finder

Optional Checklist \& Worksheet

\section{The Video}

- https://www.youtube.com/watch?feature=player detailpage\&v=CeND MgQPE 


\title{
Walk Score Apartment Finder
}

\author{
Https://www.walkscore.com/apartments/
}

Can also download abbreviated versions for Android and Apple devices.

\section{Toolbox = Options}

Customize to your needs

- One-on-one meetings with clients (Walk Score Apartment Finder)

- Group sessions (video, introductory brochure)

- Toolkit available on your housing authority's website

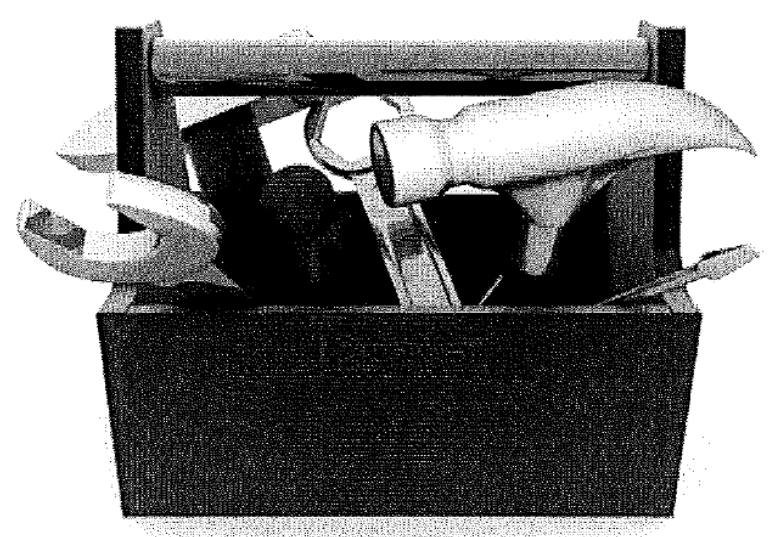




\section{Let Us Know What You Think!}

Andree Tremoulet

Center for Urban Studies at Portland State University

atrem@pdx.edu

Ryan Dann

School of Urban Studies and Planning at PSU

ridann@pdx.edu

\begin{tabular}{|c|c|c|}
\hline $\begin{array}{c}\text { S3 } \\
\text { homeforward }\end{array}$ & 19. VANCOUVER & 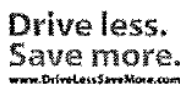 \\
\hline 9. WASHINGTON COUNTY & 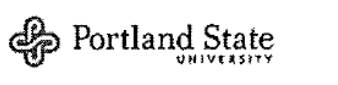 & 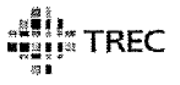 \\
\hline 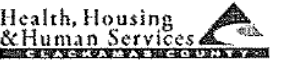 & U.S. Depariment of fronsportafion & (1) Metro \\
\hline
\end{tabular}


Transportation Research and Education Center

Portland State University

1900 S.W. Fourth Ave., Suite 175

Portland, OR 97201 